doi.org/10.46291/ISPECIJSSHvol4iss2pp28-42

\title{
ANALYZING THE GOING CONCERN UNCERTAINTY DURING THE PERIOD OF COVID-19 PANDEMIC IN TERMS OF INDEPENDENT AUDITOR'S REPORTS
}

\author{
Tuba Derya BASKAN \\ Dr. Öğretim Üyesi, Kırıkkale Üniversitesi, İİBF, Muhasebe-Finans Anabilim Dalı, \\ tdbaskan@gmail.com.tr
}

\begin{abstract}
It is thought that the Covid-19 pandemic, of which effects on the world and our country are estimated to be seen more in time, will have economic and social effects on the countries, entities and people. The aim of this research is to mention the significance of the going concern and how to reflect the problems that are arisen by the Covid-19 pandemic and that may occur within the going concern, and to identify the differences caused by this situation among the auditor's reports in general. In the study, International Standard on Auditing (ISA)-570 Going Concern was generally examined and the required method to reflect it to auditor's report of entities during the states of emergency was analyzed. Since the time passed over the Covid-19 pandemic is not enough to make a financial analysis, the evaluation was conducted within the frame of ISA-570 and according to the reached results, it was determined that its effect on the going concern assumption should be included in the reports and detailed disclosures should be made in order to provide reasonable assurance to the information users. On the other hand, it was mentioned that how the effects of the Covid-19 pandemic may be included in the auditor's reports in our country within the scope of International Standard on Auditing (ISA)-570 Going Concern. It was inferred that observations may be performed on its effect on the auditor's reports of entities by making comparisons in the upcoming period.
\end{abstract}

Keywords: International Standard on Auditing (ISA)-570 Going Concern, Covid-19 Pandemic, Audit Reports, Crisis Management.

Jel Code: M40, M41, M42

\section{COVID-19 PANDEMİ SÜRECINDE İSLETME SÜREKLILIĞIINDE ORTAYA ÇIKAN BELİRSIZLLIĞİiN BAĞIMSIZ DENETIM RAPORLARI AÇISINDAN İNCELENMESI}

\section{ÖZET}

Dünyada ve ülkemizde etkilerinin zamanla daha çok görüleceği düşünülen Covid-19 salgınının ülkelere, işletmelere ve insanlara ekonomik ve sosyal etkileri olacağı düşünülmektedir. Bu çalışmanın amacı, işletmelerde sürekliliğin önemine değinilmesi, Covid-19 (Koronavirüs- Kovit-19) pandemesinin getirmiş olduğu işletme sürekliliğindeki meydana gelebilecek sorunların denetim raporlarına nasıl yansıtılacağı ve denetçilerin raporlarında bu durumun getirdiği farklılıkların genel olarak bir tespitidir. Çalışmada Bağımsız Denetim Standard1-570 İşletmenin Sürekliliği Varsayımı genel olarak incelenerek, olağanüstü durumlarda işletmelerin denetim raporlarına nasıl yansıtılması gerektiği analiz edilmiş̧ir. Covid 19 pandemisi üzerinden mali analiz yapabilmek için yeterli zamanın geçmemesinden kaynaklı ancak BDS-570 çerçevesinde değerlendirme yapılabilmiş ve ulaşılan sonuçlara göre işletmelerin sürekliliği varsayımına etkisinin raporlarda yer verilmesi gerektiği ve bilgi kullanıcılara makul güvence sağlanması için ayrıntılı olarak açıklamaların yapılması gerektiği saptanmıştır. Diğer taraftan Bağımsız Denetim Standardı 570 İşletmenin Sürekliliği Varsayımı'nın Covid-19 pandemisindeki etkilerinin dünya da ve ülkemizde denetim raporlarında nasıl yer verilebileceği, ilerleyen süreçlerde denetim raporlarındaki etkisine karşılaştırmalar yaparak tespitler yapılabileceği sonucuna varılmıştır.

Anahtar kelime: BDS-570 İşletme Sürekliliği, Covid-19 Pandemisi, Denetim Raporları, Kriz Yönetimi

Jel Kod: M40, M41, M42.

Year 4/ 2020, Volume-4, Issue-2 | www.ispecjournal.org 


\section{Introduction}

Entities continue their life separately from their owners in accordance with the principle of continuity as from their establishment. In the general communique on the accounting system, it was stated as, "The concept of going concern expresses that entities will continue their operations without being dependent on the time. For this reason, the lives of entities are not dependent on the lifespan of their owners or shareholders. The concept of going concern underlies the principle of cost" (General Communique on Accounting System No.1). International Standard on Auditing (ISA) regulates going concerns and the obligations of the auditor regarding the auditor's reports of going concern. It is regulated with the assumption stating that an entity has an unlimited lifespan and its operations will also continue in the future. Financial statements are prepared in accordance with the going concern principle as long as the entities do not have to make liquidation decision or terminate their business operations. (ISA-700-Paragraph A2)

Sometimes, business managements may encounter some states of emergency, which can be regarded as crises, while they prepare their financial statements and continue their operations in accordance with the principle of continuity. Regarding the Covid-19 pandemic, entities operating on the industries, which are effective on the national economies, such as transportation, food, health, textile and information, may have the opportunities to provide the continuity of their going concern if they have a foundation at the level of being able to adapt to this process or if they can create a system to provide this. The states of emergency, which affect the going concern, usual business operation processes and financial structures of entities, require entities to perform new adjustments and enterprises. In this regard, first, the prevailing crisis situations, managing the crisis process, planning the going concern and the effects on the auditor's reports will be reviewed in the study.

\section{Crisis Management and Types of It in Entities}

While it is not possible to make a generally accepted definition of the concept of crisis in terms of business management, it is a concept that is mentioned among the other concepts such as concern, fear, stress, panic, disaster, etc. in the literature. It can be defined as the state of being incapable under the situations raising difficulties for persons or entities (Baran, 2012 26). According to another definition, a crisis is the process of uncertainty and obscurity emerging in the face of unexpected events (Keskin 2006, 16).

Year 4/ 2020, Volume-4, Issue-2 | wWw.ispecjournal.org 
Considering the characteristics of crises in general terms, we can list the main ones as follows.(Baran 2012, 26 and Tagraf and Talat 2003, 150).

- They cannot be predicted before and fast decision-making is necessary.

- The standard decision-making mechanisms applied in the entities may not be effective solutions in the crisis atmosphere.

- Crises may jeopardize the existence of entities.

- Assets of the managers or entity owners may be imperiled during the times of crisis.

- There is time pressure.

- Financial problems may also arise with the difficulties in controlling.

- Scenes of fear and panic may arise among the entities.

The risks, which are effective in the emergence of the crises, developed by COSO are classified as follows (Keskin 2006, p. 80).

1- External Risks: advancing technology, amended laws, customer portfolio, etc.

2- Internal Risks: restructuring of entities, borrowings, attitude and behaviors,

3- Changing environmental factors

When we look at the types of crises seen in the entities, it is possible to list them as; environmental problems, conflicts with partners or managers, strikes performed by employees, amendments, bankruptcy, handovers and natural disasters. Business managers are responsible for managing the period of crisis when encountered with a financial problem or a natural disaster and providing the going concern. In a crisis atmosphere, the first situation to be seen is the fact that entities turn the crisis into an opportunity, that is to say, use it in the interest of the entity, and the second situation is the fact that some entities make serious mistakes and put their continuity at risk during this period, and they downsize with financial failure and go into liquidation in time. 
For the going concern, first, entities should form emergency management, then the stages required to ensure the business continuity should be completed, and, finally, crises should be managed properly.

Figure 1. Emergency-Business Continuity - Crisis Management Hierarchical Model

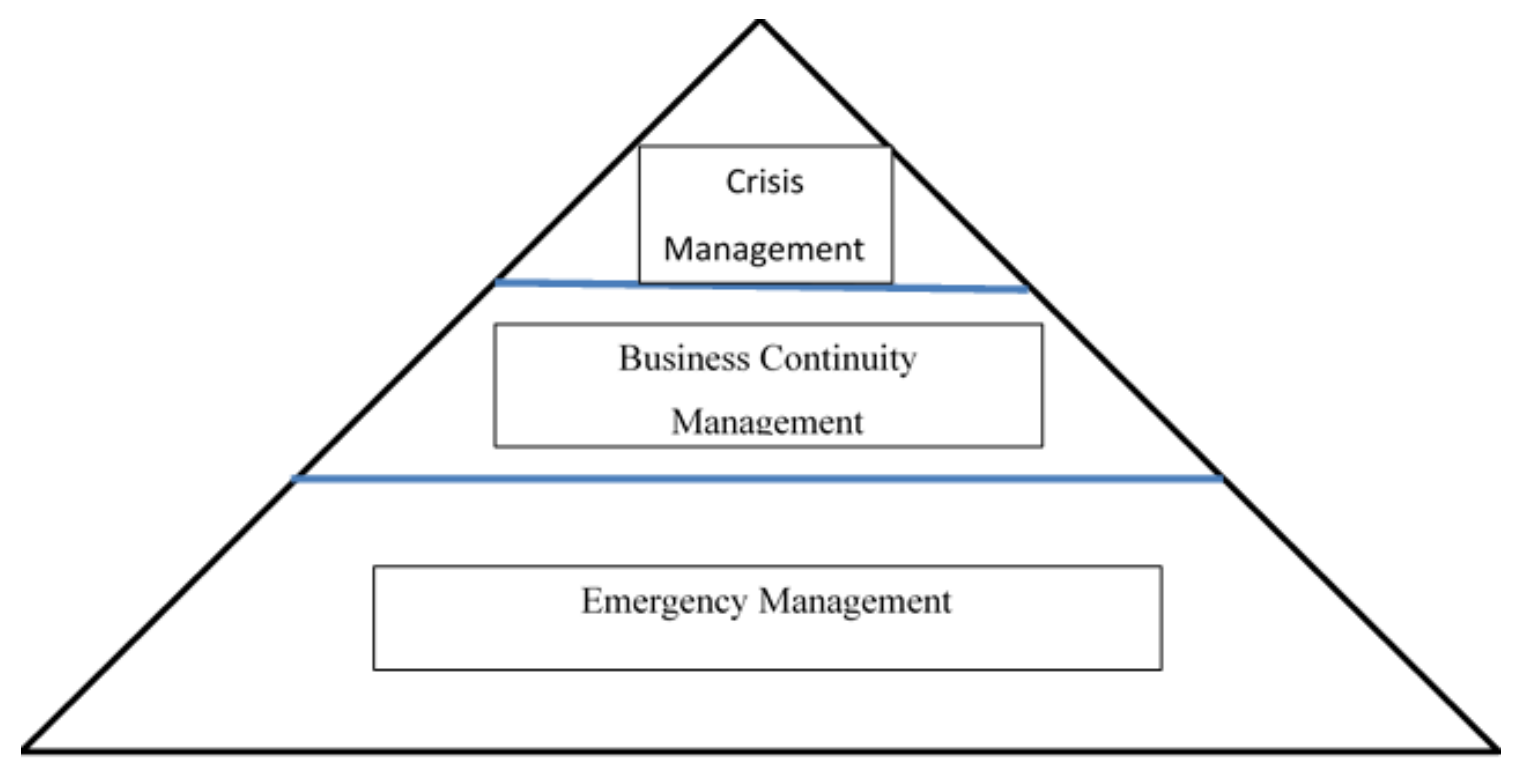

Reference: Komut 2013: 104.

As it is seen in the figure above, there are three main concepts regarding the going concern (Komut 2013, 104-105).

1- Emergency Management: Entities' ability to cope up with all kinds of restrictions terminating the operations of entities and persons in terms of the going concern, to plan and to ensure the continuity can be defined as "emergency management".

2- Business Continuity Management: It is the management of all processes required to be able to continue the assets of the entities during the states of emergency.

3- Crisis Management: The events taking place during the situations arising above the usual operations of the entities and risking the going concern, reputation, brand and reliability of the entities.

The going concern is the most important factor during these periods of crisis. At this point, internal and external factors faced by the entities should be well-detected and planning should 
be performed. As well as the crises predicted by the entities, natural disasters, which they cannot predict, emerge as a serious situation before both countries and entities.

The coronavirus pandemic, which was first found in the Wuhan, China in December 2019 and shortly spread to both the world and our country, emerges before us as a natural disaster and it is of great importance for entities to be managed properly and their continuity to be ensured.

At this stage, International Standard on Auditing 570 (ISA 570) - Going Concern standard will be analyzed and the importance of understanding the going concern assumption in entities, including it in the independent auditor's reports on going concerns, and explaining how the continuity should be approached will be examined.

\section{Effects of Covid-19 on Auditor's Reports}

Declared as a pandemic by the World Health Organization, Covid-19 creates challenges in the business lives of people as well as their social life. Many regulations are accompanied by education turning into an online system, many people trying to carry out their businesses remotely, physical business life ceasing or decreasing far too much, restrictions being imposed in many areas such as production, trade, and transportation, and the effect of curfew ordered in our country and other countries at intervals. It is estimated that independent auditor's reports will be prepared and considered within the frame of this period.

International Standard on Auditing (ISA) defines the auditor's report as; "the document through which the auditor has the opportunity to express his/her opinion as a result of his/her inspections on the matters concerning whether the financial statements reflect the truth about the financial state and operating results of the related entity as of the completed accounting period and whether they are prepared in accordance with the generally accepted accounting principles" (Yanık and Karatas, 2017:5). The auditors do not concern themselves with the incomes and expenses received by entities or with their financial structures; they only check on these emerging situations and disclose if they are proper in the financial reports or not in their reports with satisfactory evidence.

International Auditing and Assurance Standards Board (IAASB) started a project named "new auditor's report" in 2011 in order to increase the reliability of auditor's reports, to issue a more transparent report for the information users and to provide information easier among the information users and entities (Cagıran and Varıc1, 2019:195). Entities include the titles of Year 4/ 2020, Volume-4, Issue-2 | WWW.ispecjournal.org 
auditor's opinion, bases of the auditor's opinion, key audit matters, obligations of the management and the ones responsible for the senior management regarding the financial statements, report on the other obligations arising from the legislation in the auditor's reports (Yanık and Karatas, 2017:5). The auditor's reports prepared before the new auditor's reports were plainer, but the statements are still given in the same way in the section where auditor's opinions are stated. In order to avoid this, auditor's reports should provide the proper trust environment at an advanced level. In terms of information users, auditors should inspect the reports and sufficient, true and explicit information are needed to be received. There are regulations conducted in our country regarding this issue and as from the date of 01.01.2018, 'key audit matters' are implemented in the auditor's reports during the accounting periods of entities subject to the independent auditing in accordance with the Turkish Commercial Law No. 6102 following the date of 01.01.2017. The fact that the previous auditor's reports are complicated and there are large numbers of qualitative disclosures in the reports has created this need. In the new auditor's reports, there are key audit matters differently from the previous ones and auditors state the parts which they regard as important and on which they focus during the auditing differently from the previous reports. (Cagiran and Varıc1, 2019:196). It is expected that auditor's reports include the consequences caused by the period of the pandemic we are experiencing within the scope of "key audit matters".

Considered within this scope, the Public Oversight Authority (POA) has shared some disclosures and main stages significant to the auditors on their webpage in order to assist the auditors and audit institutions. The executives of POA have discussed the processes of acceptance of auditing contracts, planning the auditing, and risk assessment, their materiality levels, audit evidence, going concerns and key audit matters and included their effects on the auditor's reports on their webpage (www.kgk.gov.tr; Gokgoz 2020).

\subsection{Acceptance of the Auditing Contracts}

In order for entities to be accepted by a new auditing firm, their previous auditor's reports have to be reviewed. While some of the studies can be evaluated remotely, since some of them are not possible to be evaluated remotely and the uncertainty of the duration of this pandemic period, auditing firms may have difficulties in accepting the new contracts. Again, the spread of the pandemic also complicates the communication network among the buyers, sellers, banks, and certain government institutions. Under these circumstances, some 
adjustments should be performed on the contracts by amending the items regarding the delays in the auditing process and report dates, delays in the notifications that are required to be presented to the related persons, and the process and scope of the auditing.

\subsection{Audit Planning and Risk Assessment Processes}

Due to the uncertainty of this period, while audit planning and risk assessment procedures cannot be completely carried out, difficulties may be experienced in terms of deciding the necessity of auditing procedure applications and this may cause some significant mistakes. There may be weaknesses occurring in the operations and audit planning of the entities during the times when natural disasters and states of emergencies are experienced. Within this scope, the agreed decisions should be approached in the most proper way and the auditing risk process should be approached in accordance with the needs. In some cases, there may be unusual amounts or disclosures by the force of current circumstances. Auditors determine if this kind of disclosures or amounts are necessary or not in accordance with the materiality rinciple and this account balances or disclosures should be deemed necessary by considering the circumstances experienced by the entities in which the auditing is conducted. It will be appropriate to consider the effects of states of emergency while evaluating the materiality and risk levels during auditing processes, which are not completed regarding the period of December 31, 2019, and re-evaluate them.

\subsection{Audit Evidence}

Auditors prepare independent auditor's reports in line with the audit evidence they obtain while they are reporting. Since not obtaining enough evidence in proper conditions may reduce the reliability of the auditor's reports, auditors may need more technological support in order to reach this evidence. The documentation related to this evidence has the risk of reducing the quality and reliability of this evidence through auditors. Therefore, auditors need to try alternative ways and evaluate the adequacy and quality of the evidence to be obtained and specify the results they reach on their working papers.

\subsection{Going Concern}

Since the duration of the Covid-19 pandemic is not known, being able to make a comment on the going concern of the audited entities is not easy. As it will be explained through the International Standard on Auditing (ISA) 570-Going Concern in the upcoming sections, it can Year 4/ 2020, Volume-4, Issue-2 | www.ispecjournal.org 
be said that adequate and proper audit evidence should be obtained in order for entities to use the principle of continuity of the management, and concluding if the entity has a significant hindrance to continue the going concern or not will be enough.

\subsection{Key Audit Matters}

According to the International Standard on Auditing (ISA) 700-Key Audit Matters, the effect of the Covid-19 should be approached as a key audit matter considering the stated conditions. Hence, it should be presented in a separate paragraph within the scope of the effects of the pandemic. It will be appropriate to refer to these disclosures in the "Matters to Consider" section of the auditor's report. In this paragraph, it should be stated that enough evidence cannot be gathered due to the pandemic and under these circumstances, in which the going concern principle is uncertain, another opinion apart from the positive opinions may be given in the auditor's reports. As the basis of this opinion, disclosures about the Covid-19 should be provided and the fact that current transactions cannot be conducted due to the pandemic and if the confirmation and disclosures on the amounts are enough or not with the alternative auditing methods should be disclosed.

Considering the fact that continuity of the operations of the entities is one of the most important factors, the issues by which the entities are affected during the auditing process are stated above. Surely there will be impacts of this period which affects both the world and our country.

\section{Going Concern}

The going concern is an economic requirement for the national economies. The fact that the going concern is limited negatively affects the information users such as investments, creditors, partners, employees, and institutions such as the state. On the other hand, the going concern is one of the main concepts of accounting and not dependent on the lifespan of the owners or shareholders in accordance with the assumption stating that the lifespans of entities are unlimited (Tepegoz and Turedi, 2015:44).

When the past is considered, it is seen that the concept of going concern was approached by accounting authorities in the world and it dates back to old times. While the Financial Accounting Standards Board (FASB) mentioned about the going concern in 1953, the U.S. Securities and Exchange Commission evaluated the going concern in 1962. The matters to Year 4/ 2020, Volume-4, Issue-2 | www.ispecjournal.org 
consider in the evaluation of the going concern were disclosed in the AICPA SAS 2 in 1974 (Mert et al., 2019:121).

In our country, the concept of going concern was stated as "the operations of the entities are not dependent on a certain period of time or the lifespan of their owners or shareholders, and the concept of going concern forms the basis of the principle of cost" according to the General Communique on Accounting System. A communique about the International Standard on Auditing (ISA)-570 Going Concern was published on the Official Gazette by the Public Oversight Authority (POA) on the date of January 23, 2014. According to this communique, the going concern assumption is stated as, "operations of the entities will be conducted in the future, they will not be liquidated and the continuity will last" (Communique on the ISA 570, Turkey Auditing Standards Communique No. 25, Article 2).

While the financial reporting of the entities is being prepared, one of the fundamental grounds is the fact that usual operations will continue and will not be liquidated. In this case, auditing institutions should gather adequate and proper audit evidence within the scope of the going concern assumption and conclude if the entities have a material uncertainty regarding the going concern or not. ISA 570-Going Concern standard is issued within this scope. According to this standard, the going concern and the effects of it on the auditor's reports were issued. (ISA 570, art. 1). It states the going concern continuity levels and matters to consider in accordance with these matters (ISA-570, art. 3). The standard discloses the responsibilities of auditors regarding the entities as, "to obtain sufficient and appropriate audit evidence about the appropriateness of management's use of the going concern assumption in the preparation of the financial statements and to conclude whether there is a material uncertainty about the entity's ability to continue as a going concern, and to conclude there is a material uncertainty about the entity's ability to continue as a going concern by depending on the audit evidence" (ISA-570 art.6). In this respect, standard states that auditors shall express their opinions by considering that there is not a material uncertainty in the continuity of the going concern assumptions (ISA-570, art.8). Auditors shall perform a risk assessment in order for continuity of the going concern (ISA-570, art.10) and if events or conditions have been identified that may cast significant doubt on the entity's ability to continue as a going concern, the auditor shall obtain sufficient appropriate audit evidence to determine whether or not an uncertainty exists through performing additional audit procedures (ISA-570, art. 16).

Year 4/ 2020, Volume-4, Issue-2 | www.ispecjournal.org 
As a result, there are lots of regulations issued by accounting authorities both in the world and our country with reference to the going concern assumptions and, today, going concern assumption can be updated. In this regard, in the last section of the study, the effect of uncertainty occurring in the going concern on the audit reporting processes, the importance of the going concern attached by auditors, and the interpretations on the effects of the period we live in on this process will be presented.

\section{The Effect of the Period of Covid-19 Pandemic on Going Concern in Preparing the Auditor's Report}

While the Covid-19 pandemic is expected to have significant effects on the going concern, it may not be possible to identify its effects definitely. Auditors need to consider this current period while preparing the auditor's reports.

In order to ensure the proper trust environment regarding the auditor's reports, they should perform professional, standard, and evidence-based reporting (Yanık and Karatas, 2017, p. 4). The increasing trust environment regarding the reporting, which is a significant communication tool between the entities and information users, brings along economic outcomes. That's why the information in the auditor's reports of entities should be prepared with correct, truthful, and realistic opinions. (Kavut and Gungor, 2018:60).

In the process of issuing the auditor's reports, conditions of the entities against their competitors and within the country should be properly determined. Information users, who wish to receive information about the entity, request both financial and nonfinancial information during the changing environmental conditions such as technological changes and a crisis situation experienced in the country. In this stage, during which the going concern is significant, the auditor's reports should be prepared within this framework.

Situations such as dismissing the employees from employment, closing the branches and stores, terminating the operations, and delays in recovery of debts should be evaluated by auditors. Since performing a financial analysis by inspecting the state of this pandemic emerging in the world and our country in the financial reports will be meaningless due to the time passed over the pandemic is not enough in this stage, some evaluations will be made on the going concern within the scope of IAS-570. According to these evaluations, the subject

Year 4/ 2020, Volume-4, Issue-2 | WwW.ispecjournal.org 
headings stating the imperilments regarding the going concern can be listed as follows: (ISA 570, A3-A4).

- Net liability of entities in the short term,

- Excessive reliance on short-term borrowings to finance long-term assets,

- Difficulties in finding financial support in the market,

- Problems in historical or prospective cash flows, the negative situation in financial analyses,

- Increase in the operating losses and deterioration in generating cash flows,

- Inability to pay defaults,

- Difficulties in conducting the principal activities of the entity,

- Inability to pay creditors on due dates,

- Management intentions to liquidate,

- Key management requesting to leave,

- Difficulties in competing,

- Increase in the number of lawsuits brought against the entity,

Although these situations stated by the standard do not indicate a certain problem in the going concern, the auditors should conduct comprehensive research while expressing opinions in the auditor's reports. Because, considering the final point reached by the auditors in the auditor's reports is expressing opinions on the entities, the state of expressing positive, negative, and qualified opinions or not expressing any opinion at all may be affected during the situations when the going concern is imperilled.

While the answers to the questions asking how entities will be affected by this current period and how this situation will be reflected on the auditor's reports may be revealed in the upcoming periods, it was tried to determined that what should be considered by the auditors regarding the auditor's reports within the scope of IAS 570.

Year 4/ 2020, Volume-4, Issue-2 | WwW.ispecjournal.org 
- Entities may demand the management perform evaluations regarding the continuity. Auditors should demand the owners and the board members of the entity to evaluate the current situation of the entity, their plans for the future and the yields of these plans in favor of the entity in the case that they are implemented and to present these evaluations (IAS 570, par.16).

- In case that a change in the cash flow forecast of the entities is predicted or states of emergency are experienced, this situation should be considered in the assessments of going concern (IAS 570, par.16).

- In case that there is a new situation arising after the assessment process conducted by the management or owners of the entity, they should request additional information (IAS 570, par.16).

- The auditors may request future planning from managers during the states of emergency. They may question if the management has plans for future actions such as liquidate assets, borrow or lend money or restructure debt, reduce or delay expenditures, and increase capital. The auditor may compare the current situation of the entities with prior periods through estimated interpretations during the current Covid-19 pandemic (IAS 570, par.16-c).

- In the assessments performed regarding the going concern, the realization of the future operations and implementations of the plans may have to be supported with audit evidence. In this case, auditors may receive audit evidence with a special written statement.

- While expressing their opinion on going concern, if there is an emerging doubt or an existing material uncertainty, in order to determine the magnitude and effect of this situation, they should provide the necessary disclosures in order for information that will be presented in the financial reporting not to be misleading. Accordingly, the auditors should conclude on whether this kind of uncertainty exists or not (IAS 570: par.18-19). The independent auditors may express an adverse opinion in case there is a doubt regarding the going concern. They do not have to express an adverse opinion if they provide adequate disclosures about the going concern in their reports and the necessary information on the financial statements are provided in the annotations. In

Year 4/ 2020, Volume-4, Issue-2 | www.ispecjournal.org 
the case that the number of uncertainties is high and the necessary disclosures are not provided in the financial statements, the auditors may express a qualified opinion or adverse opinion (Almalı 2009: 90-91).

The auditors shall consider some situations regarding the entities they audit due to the uncertainty caused by the Covid-19 pandemic both in daily life and business life. The auditors shall prepare auditor's reports by evaluating the questions stating that whether the entities have enough liquidity power or not, how the cash flows of entities will be affected with the extension of the period of pandemic and whether this cash position is adequate or not, whether the entities will have the opportunities to make new investments or not and what are the opportunities to find new sources, and by addressing the effects of these on going concern.

\section{Conclusion}

The Covid-19, which is a type of coronavirus described as "a large family of viruses that may cause illness among animals and humans" by the World Health Organization, has turned into a huge epidemic worldwide, including our country. This coronavirus illness, which is now accepted as a pandemic in the world, has turned into a big crisis risking human health.

Entities will be able to minimize the losses that may be caused by the Covid-19 pandemic, and some of them even will be able to come out ahead from this situation according to the industries in which they operating and whether they are ready for the crisis. Considering the performed auditor's reports, it is observed that there are not many details regarding the going concern in the auditor's reports. The experienced crises (Covid-19 should be regarded as a crisis) may present a threat risk in the going concern and bring along many bankrupt enterprises. The significance of going concern is emphasized on the standards of accounting and financial reporting and independent auditing standards, and responsibilities have been conferred on the managements and auditors regarding this situation. Independent auditing firms have to issue auditor's reports by considering the Covid-19 pandemic along with their year-end reports and have to state the fact that there is not a situation posing as a threat for the going concern based on the evidence in their reporting. The communique on the going concern (ISA-570) states that entities will continue their operations in the future and the financial reports will be issued accordingly as long as there is not a planning on terminating the operations of the entity or liquidating by the management.

Year 4/ 2020, Volume-4, Issue-2 | WwW.ispecjournal.org 
In conclusion, the auditors should address the necessary conditions in order to increase the reasonable trust in independent auditor's reports and in order for going concern to be created. Detailed research should be conducted on the entities and they should state the received results on their reports. The interpretations to be made on the auditor's reports about the going concern are of importance for the groups such as creditors and investments. The study aims to review the issued auditor's reports and to analyze and interpret the changes and adjustments, if any.

\section{References}

Almalı, Z. (2009). An Importance of Business Continuity Concept in Independent Audit Process, Master Thesis, Marmara University Institute of Social Sciences, İstanbul.

Baran, H. (2012). Crisis Management in Business, Research and Professions Development Directorate Bulletin, izto.org.tr., 26-32.

Çağıran, F.K.; Varıcı, İ. (2019). Key Audit Matters Within The Framework Of Isa 701: An Analysis On Audit Reports Of Companies Listed In Bist Manufacturing Industry, International Journal of Economics and Administrative Studies, 22, 193-208.

Gökgöz, A. (2020), Considerations for the Covid-19 Outbreak in Independent Audit, www.maliye.gov.tr, (date of access: 17.04.2020).

Kavut, F. L.; Güngör, N. (2018). Key Audit Matters in Independent Audit: An Analysis on Firm Listed In The Bist-100 in 2017. Journal of Accounting Institute, 16(59), 59-70.

Keskin, A.D, (2006). Internal Control System Control Self Evaluation, Beta Publishing, İstanbul.

Komut, M. (2013), Business Continuity Organization, İ.Ü. Journal of Faculty of Political Sciences, 49, 101-116.

Mert, H., Güner,M. ve Duyar, G. (2019). The Investigation of the Effects of the Going Concern Standard on the Audit Reports, Accounting and Auditing Review, 57 : 119-140. 
Tağraf H. ve Arslan, T.N. (2003). The Process of Crisis Occur and The Proactive Crisis Management Aproach, Cumhuriyet University, Journal of Economics and Administrative Sciences, 4(1), 149-160.

Tepegöz, Ş.M. ve Türedi, H. (2015). "Business Continuity Assumption and Auditor's Responsibility”, Erzincan University Journal of Social Sciences Institute, VIII-II, 43-52.

Yanık, S.ve Karataş, M. (2017). The Future of Audit Reports: New Regulations and Country Practices, The Journal of Accounting and Finance, 73, 1-25.

www.kgk.gov.tr., TSA 700- Forming an Opinion and Reporting on Financial Statements. 